DEVELOPING DESCRIPTIVE WRITING MATERIAL THROUGH TEXT-LESS COMIC FOR GRADE X OF SMA GEMA BUWANA

\author{
AN ARTICLE \\ Submitted in Partial Fulfillment of Requirements \\ for the Degree of Sarjana Pendidikan
}

By:

FITRI ATIKA

Registration Number: 2143121014

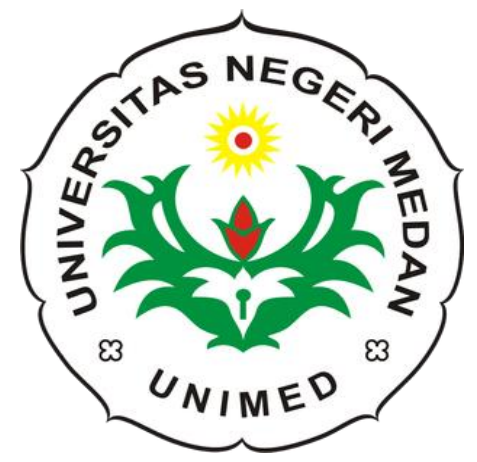

ENGLISH AND LITERATURE DEPARTMENT

FACULTY OF LANGUAGE AND ARTS

STATE UNIVERSITY OF MEDAN

2021 


\title{
DEVELOPING DESCRIPTIVE WRITING MATERIAL THROUGH TEXT-LESS COMIC FOR GRADE X OF SMA GEMA BUWANA
}

\author{
FITRI ATIKA*
}

YENI ERLITA**

\begin{abstract}
Atika, Fitri. Registration Number: 2143121014. Developing Descriptive Writing Material Through Text-Less Comic for Grade $X$ of SMA GEMA BUWANA. A Thesis, English Educational Program, Faculty of Languages and Arts, State University of Medan, 2021.
\end{abstract}

The aim of this study was to develop descriptive writing material through text-less comic for grade X of SMA GEMA BUWANA. The research was conducted by using Research and Development (R \& D) design through six stages; gathering data and information, analyzing data, designing text-less comic, validating by the experts, revising and final product. The subject of the study was grade ten of SMA GEMA BUWANA. The data were gathered by administering interview to English teacher and distributing questionnaire to 25 respondents to get the students' needs. The interview and questionnaire result prove that the students need text-less comic in teaching writing which can stimulate students' ability and develop thinking process through looking for, guessing, and logically. Using text-less comic in learning process also helps students to understand the material by themselves. The product has been validated by an English lecturer and an English teacher with the interval was 4.3. The product was categorized as "Very Good" descriptive writing material through text-less comic. The final product of this study was a material of developed descriptive writing material through text-less comic, it consisted one part that has 3 kinds of descriptive cover the learning needs.

Keywords: Text-Less Comic, Descriptive Writing Material, Research and Development $(R \& D)$

\footnotetext{
*Graduate

$* *$ Lecturer
} 


\section{INTRODUCTION}

The Background of the Study

Language is an effective way of communication of our feelings. Therefore, it is may be confined only to human beings for communication intention. Carney (1990) defined language as a set of a few specified vocal symbols that help to human beings to communicate with others. According to Hadely (2001), language is a set of sounds by means of which feelings, thoughts and sentiments are conveyed to other human being. A newly born baby is unable to speak.

According to Hyland (2002:91) writing is a recursive process which consists of some stages namely prewriting, writing, editing, revising, publication and appreciation. All of the stages are aimed to improve students writing skill through some revision and help the learners to evaluate how well they have developed a text to give meaningful information for the readers.

Therefore the role of teacher is highly needed to motivate and achieving students' understanding in writing descriptive text. Agustiningsih (2015:55) maintained that teacher's creativity is a factor that determines the successful of teaching and learning process. This means teacher's creativity could influence student's understanding in learning descriptive text. On the other words, teachers need to prepare everything before teaching which were leading to a better understanding for students about the material which is given by the teachers.

In line with the important of selecting materials, Dirgeyasa (2014) explains that providing appropriate learning materials based on students' need is important, because the using of the materials significantly determine the achievement of teaching learning. 
Meanwhile, based on preliminary observation result in X grade of SMA Gema Buwana academic year 2018/2019 at $15^{\text {th }}$ of February 2019, the teacher still uses conventional teaching technique and still uses textbook as the teaching media in the teaching and learning process. In teaching and learning process, students were just asked to do some instructions based on the text book. This kind of teaching technique is the result students have less comprehension of English material, especially in writing.

Based on the fact above, the developing of English writing material is needed for students to learn writing a text. The researcher will conduct a study on "Developing English Writing Material for grade X of SMA Gema Buwana".

\section{REVIEW LITERATURE}

\section{Writing}

Writing is the one of the basic skill of the English language. It is generally considered one of the most difficult that other skills for foreign language students. Even native speakers feel difficulty in showing a good command of writing (Johnstone, Ashbaugh \& warfield, 2002). While Langan (2001:76) arguments "writing is transferring oral language into writing language".

Syarif (2004:4) explains, Writing is indirect communication which we transfer our thought and feeling grammatical and vocabulary with symbol written. It means that written deal the content and basic what we have written by explore and distinguish our thought and feeling.

Harmer (2004:31) explains, Writing encourage students focus on accurate language used and because they think as they write, it will provoke language development as they resolve problems which the writing puts into their minds. 
According to Watkins (Widodo, 2008:101), Writing is not only a toll for communication, but also it serves as a means of learning, thinking, and organizing knowledge or ideas.

According to Boardman (2008:18-25) there are three characteristics in writing a good text or paragraph, namely:

\section{Coherence}

A paragraph has coherence when the supporting sentences are ordered according to principle. The sentences are put in order so that the reader can understand your ideas easily. The principles for ordering depend on the types of paragraph you are writing. Coherence means stick together, coherence is basically a matter of having the part of a piece of writing in the right with the clear process.

\section{Cohesion}

Another characteristic of a good paragraph is cohesion. When a paragraph has cohesion, all the supporting sentences connect to each other in this support of the topic sentence.

\section{Unity}

The final characteristic of a well written paragraph is unity. All the supporting sentences should relate to the topic sentence. Order in text or paragraph is like organization easy, but is smaller in space so it may be simpler to consider order as direction. Thus order chronological steps to express the idea the written from.

\section{Writing Process}


When students write, they should know what to write and how to write. Carol (2001:15) states that the process of writing occurs in several stages:

a. Prewriting, choosing a topic and beginning to gather and organize details.

b. Drafting, getting ideas down on paper in taught the format that intend for the finished work.

c. Revising, the stage in which rework the first draft to improve its content and structure.

d. Editing and proofreading, correcting errors in grammar, spelling, and mechanics.

e. Publishing and presenting, sharing the work with others.

Writing Aspect

Aspect of writing (Hughey:1983) consists of grammar, form, mechanic, vocabulary, and style. The following aspect can be explained as follows:

\section{Grammar}

Grammar is employment of grammatical form and syntactic pattern. It means that sentence is another aspect that should be considered.

\section{Form (Organization)}

Form means the organization of the content. We should clarify our idea and make it clear. So, the reader can deduce some organization well. Organization means there is a communication between the reader and the writer.

3. Mechanic 
Mechanic is the use of the graphic convection of the language we have to pay attention the use of the punctuation and applying of the word of sentences. Function is very determiners whiter the writer can clear for the reader.

4. Vocabulary

Vocabulary is the most important aspect in teaching a language mastery vocabulary. It means that, we can explore our idea in writing.

\section{Style}

Style means the choice of structure and lexical items to give a particular tone to flavor the writing. It should be noted that the choice of lexical item to be used writing must be accordance with the readers. By seeing the opinion above, it can be said that there are five aspects in writing that have to be paid attention in writing in order to make the writing better and understand by the reader.

\section{Writing Genre}

There are many kinds of genres, Pardiyono (2007:2) divided into some kinds, and they are:

1) Description: A text which describe something in detail in order to enable the readers to see, feel, hear and touch event.

2) Recount: Contains of the chronology of activities done in the past time.

3) Narrative: Tells world event, which can be informative of entertaining and cam be past world events or present happenings. 
4) Procedure: A text that is designed to describe how something is achieved through a sequence of actions or steps.

5) Exposition: Contain instructions about a sequence of actions or narrative to do a thing.

6) Discussion: Present information or opinion about hot issue, which is sometimes controversial. Text is commonly ended with a conclusion or recommendation based on presented data after presenting adequate arguments for the controversial issue.

7) Exposition: Contain instructions about a sequence of actions or narrative to do a thing.

8) News Item: A text that inform the readers about newsworthy of important events of the day.

9) Report: contents of present information about a thing or fact supported by data presentation, characteristic description, and classification or tabulating.

10) Anecdote: contains a meaning or shares about ridiculous, shame full, funny, very special, or extraordinary events.

11) Review: To critique and give evaluation of essay, book, or artwork.

\section{Descriptive Text}

Descriptive text is a type of written text, which has specific function to give description about an object (human, non-human or idea) vividly so that the reader can visualize the object described. 


\section{Social Function}

The social function of descriptive writing is to describe a person, place or things in such a way that a picture is formed in the readers mind. In addition, the purpose of descriptive writing is to make our readers see, feel and hear what we have seen, felt and heard. Whether we are describing a person, a place or a thing, our aim is to reveal a subject through vivid and carefully selected details.

\section{Generic Structure}

The generic structure and textual elements of descriptive writing based on Dirgeyasa (2016: 58), can be explained as follows:

\section{1) Identification}

It is a statement which identifies about the topic/theme that will be described. The statement given must be interesting enough to attract the reader to read the whole explanation about the description.

\section{Descriptive}

It is the place where detail explanation about the topic is presented, as stated in the identification about the topic that is going to be described.

a. Language Features

According to Pardiyono (2007:34), the language features used in descriptive text are:

1. Use of declarative sentences

2. Use of conjunction Using conjunction is to create a coherent text

3. Use of simple present tense 
Tense used in descriptive text is present tense, because it tells about a facts, general accepted-facts, or reality. The formula of present tense is:

$S+V 1 \ldots$ or $S+$ to be (is/am/are)...

4. Use of adjective, verb, noun, adverb

b. Example

\begin{tabular}{|l|l|}
\hline Identification & $\begin{array}{l}\text { Tawangmangu Waterfall is one of the most interesting } \\
\text { places of interest in Karanganyer. }\end{array}$ \\
\hline $\begin{array}{l}\text { It is located not far from Solo. It is about 30 kilometers } \\
\text { east of the city. It is very easy to get the place by any } \\
\text { public transports. Bus is the cheapest, but taxi is the } \\
\text { most convenient. }\end{array}$ \\
$\begin{array}{l}\text { It has cool weather most of the time, no wonder many } \\
\text { people like to visit in their free time. As it is far from } \\
\text { industries of any kinds, there is always fresh and it is } \\
\text { not polluted. } \\
\text { Description }\end{array}$ \\
$\begin{array}{l}\text { The water falls more than 30 metters down into a small } \\
\text { like. The falling water looks very fantastic and the } \\
\text { beauty of the nature around the like is so astonishing. } \\
\text { There is a small river nearby, to where the water then } \\
\text { flows. } \\
\text { Table }\end{array}$ \\
$\begin{array}{l}\text { Located in the middle of pinewoods, the like is always } \\
\text { wonderful to admire. In addition, there are many funny } \\
\text { and tame monkeys climbing the trees on the left and } \\
\text { right sides of the sidewalk down to the like. }\end{array}$ \\
Example of
\end{tabular}

Source: Pasti Bisa! Teaching Genre-Based Writing (Pardiyono:2007) 


\section{Text-Less Comic}

Text-less comic is "pure" comic or picture series that contains very minimal text (Hilman, 1995:7). Text-less comic connect visual literacy (learning to interpret images), cultural literacy (learning the characteristics and expectations of social groups) and literacy with print (learning to read and write language).

A comic is a book (often shortened to simply comics and sometimes called comic paper or comic magazine) is a magazine or book of narrative artwork and (virtually always) dialog and descriptive prose. The style was introduced in 1934. Despite the term, comic book does not necessarily feature humorous subjectmatter, in fact, it is serious and action oriented. Since the introduction of the comic format in 1934 with the publication of famous funnies, the United State has been the leading producer, with only British comic and Japanese manga as close competitor in term of quantity of title. The majority of all comic books in both U.S and Japan are marketed to young adult readers, though they also produce titles for young children as well as adult audience.

Comic typically appear in three or four square-shape cells, called panels. The panels are arranged in row and are red from left to right (right to left for Japanese manga). Comics are booklet-length comics that are more stylized and tell a more involved story. They can be written in the same style as comic strips, but they also feature panels of different shapes and sizes and are red both horizontally and vertically. Most daily newspaper comics are published in black and white and most comic books produced in color.

Comic books are booklets that come in varying size, and are most often in color. The lengths of comic books allow them to tell more involved stories than comic strips can. The design of the panels can also differ from comic strips, which nearly always consist of three or four equally sized square panels per strip. In comic books, the number of panels on each page can differ, as can their size and shape. Sometimes one scene can occupy an entire page. 
Most children and young love comic because of their visual, attractive, humorous, and overall appeal (Hillman, 1995: 66). From this statement the researcher applied this text-less comic in the X grade of senior high school.

\section{Roles of Text-less Comic}

According to Hillman (1995: 167-169) text-less comic some roles in the class, they are:

1. Comics can motivate students and make them want pay attention and take part.

2. Comics contribute to the context in which the language is being used. They bring the words into the classroom.

3. Comics can be described in objective way or interpreted, or responded to subjectively.

4. Comics can cue response to questions or substitution through controlled practice.

5. Comics can stimulate and provide to be referred into conversation, discussion, the language they use and storytelling.

From the points above it can be concluded that text-less comic is very useful in learning the English language. Teacher and learners are helped by using this media to achieve the learning goals. It can solve the problem faced by the students in the process of writing especially in writing narrative text and caused them concentrate more on the orderly arrangement of story by paying attention to the text-less comic and the language they use.

\section{RESEARCH METHODOLOGY}

\section{The Research Design}

The research will be conducted by using research and development $(\mathrm{R} \&$ D) which was adapted from Borg and Gall (1985:775). R \& D is one of research 
designs aims to develop and validate the educational products, like curriculum, syllabus, texts books, instructional media, modules, or assessment instrument by Borg and Gall (1983). R \& D is used to design and produce new product and examine the new product (Sugiyono, 2011: 297). This research will be conducted by following six phases of R \& D, they are:

1. Gathering information and data

2. Analyzing existing syllabus, existing textbook especially writing materials, and students' needs.

3. Reviewing the theory of principle of effective writing materials,

4. Designing or developing writing materials,

5. Validating new writing materials to the experts,

6. Revising new writing materials as suggested by expert (final product).

This model of development is chosen because it has stages which are clear and appropriate with procedure.

The Subject of Research

The subjects of this research will be students which are in grade X SMA Yaspend Gema Buwana. The reason for choosing this school is material that used by teacher are not suitable for students' need. The teacher teaches writing Descriptive Text. The material that will teach should be writing descriptive text using text-less comic.

The Instrument of Collecting Data

The data will be collected through questionnaires, interview and observation. The questionnaires will be administered to get the data of the students and teacher. This step handled to get the data from the students about 
their interesting in English and what their problems in learning English, especially in writing materials.

The interviews will be administered to support the data of students need in learning English. Interviews session will be held to students and teacher. Interview has function to get data from the students about their interesting in English and what their problems in learning English writing material given, and to get data from the practitioners, whether the writing material matches to the students' need or not.

The observation has function to find the problems of the students in learning the writing materials.

\section{Techniques of Analyzing the Data}

The research will identify the main variables such as: Target need and Need analysis that is the need of the students of SMA Yaspend Gema Buwana. The data will be used to plan materials needed by the students.

The data are analyzed through the following steps:

1. Need analysis by using questionnaires and interviews. Questionnaires are administered to the students to get the related data. Interviews will be also administered to the practitioners to support the questionnaires, and then the data will be tabulated in order to obtain the best solution in terms of preparing what material designs are appropriated for the students of SMA Gema Buwana.

2. Designing the syllabus. Syllabus will be developed to an appropriate syllabus based on the need analysis findings.

3. Developing material. Material will be developed to appropriate material based on the syllabus designed. 
The research will identify the main variables such as: target needs weakness and needs of the students of SMA Gema Buwana. The data of target needs, weakness, and students' need are gotten from the questionnaires given to the students, the result of interviews given to the students and practitioners. The data will be used to plan the materials of writing that appropriate to the students' need.

\section{Need Analysis Questionnaire}

The data from the need analysis questionnaire will be analyzed through calculating the percentage of each answer in questionnaire by following the formula:

Description: $\quad \overbrace{\text { Percentage }(\%)=\frac{\text { Totalscore }}{Y} \times 100}$

Total Score : Result of each point

Y : The highest score $\mathrm{x}$ the number of respondents

$100 \quad$ : Fixed number

2. Expert Judgment Questionnaires

Likers-Scale will be used as the measurement to analyze the data of expert judgment questionnaire. The results of the questionnaire will be calculated by using the formula proposed by Suharto (2006: 52-53).

\section{Steps of Developing Material}

The steps of developing materials are:

1. Gathering information and data by giving questionnaires, having an interview session with the teacher of Gema Buwana. After that, the writer will check the existing material (text book). 
2. Analyzing the students' needs based on the data and information.

3. Designing the English writing material based on the students' needs.

4. Evaluating or validating the draft of development. The writer will give it to the experts, in this case there would be 2 experts, the first is the English teacher and the second is the lecturer. This stage will avoid the misleading in the text and will make sure the texts completes to cover the students' needs.

5. Revising the writing materials based on the experts' suggestions.

6. Revised-Developing writing materials (final product)

Here is the flow chart of developing the materials by Borg And Gall (2003):

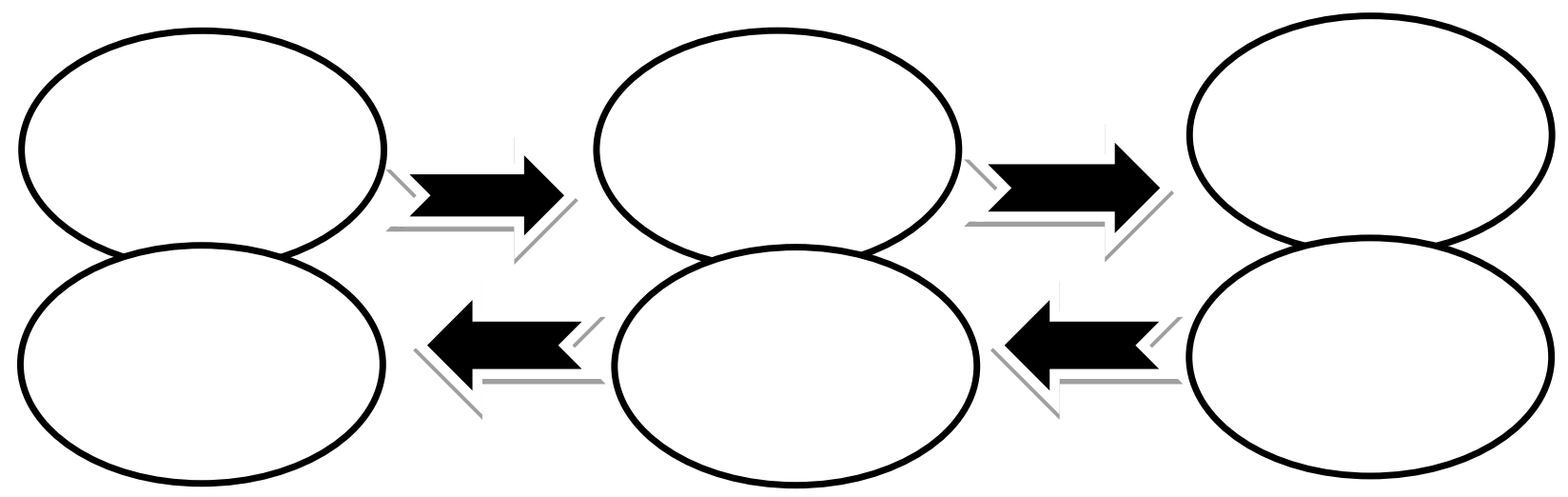

Figure diagram of Material Development

\section{RESEARCH FINDINGS AND DISCUSSION}

\section{Research Findings}

This chapter showed the result of the research. The data of this research was obtained by validating the product. The kind of product was students' material. The students' material were developed through six phases, such as: Gathering the Information and Data, Analyzing the Data, Developing the material, Validating the material, Revising the Product, Final Product. 


\section{Gathering Information and Data}

Gathering information had been done before starting the research. It was supposed to get the problem of the study. There were some informations gathered such as the book used or existing materials, learning activity and students' quessionnaire. The detail information was needed to develop students' material related to the students' need. The quessionnaires were distributed to twenty five students of grade ten. The quessionnaire consisted a number of questions which covered the description of the students' target needs and learning needs.

\section{Analyzing Data}

Need analysis is a basis of conducting this research. It was aimed to gain the information about the students' opinion need and interest the data were taken by interview list and questionnaire sheet. The interview and the questionnaire sheet were used to know experts' opinion and respond about the students' material in writing skill for grade $\mathrm{X}$ of SMA Gema Buwana. The students' material was developed which can fulfill the students' need. 
The Description of the Students

The respondents of the need analysis questionnaire were the students of grade $\mathrm{X}$ at SMA Gema Buwana. The description of the respondents is presented in the following table.

The respondents consisted of 10 male and 15 female. The age of the respondents was around 14-16 years old.

\section{Interview Analysis}

Interview session was administrated to the English teacher too by the researcher. It was conducted to support the result of the questionnaires analysis and also get the accurate data, the interview was consist 13 questions. The teacher was response in interview session that given below:

By analyze the data both the existing students' worksheet and need analysis including the questionnaire and interview administrated to the English teacher grade X, this study can identify than the existing of students' worksheet especially in writing skill based on the teachers' opinion.

The Description of Target Needs

Necessities

Most of the students needed writing skill in English to be able to do learning activity effectively in the class (56\%). The necessity of the students for provides materials that lead students to reach the learning objective by providing the tasks to support the students' learning effectiveness. For students needed English to continue their study to postgraduate $48 \%$. They also needed English to do job $28 \%$. Students' necessity was found that the students had a motive of learning English to continue their study to the higher level and also to do job. The difficulties in writing English that $44 \%$ of the students felt a little bit difficult to wrote in English in various situations and condition by using various topics.

Students had difficulty in applying grammar to the sentences (52\%) and they have low vocabulary in finding the appropriate words for the sentences 
(24\%). The lack of the students, the materials containing some grammar and vocabularies activities related to the topic. From the students' point of view $40 \%$ of them wanted that the English learning process of writing can help them to master the vocabulary in English. They also wanted the materials that can help them to master the grammar and technique of writing.

To accommodate the students' want, various activities are provided to lead students to write in English well by accommodating the words, sentences pattern that will used to practice writing. The goal of the students $56 \%$ of the students learn English writing to help them in mastering the vocabulary in English in order to understand spoken and written text and $24 \%$ of them learn English to be able to master the grammar well in writing learning process. So, to accommodate their goal, this workbook provides various activities which lead them mastering vocabulary. students wanted to have topic about education in learning writing as $52 \%$ of the students voted for this topic and $24 \%$ of them chose topic of daily activities.

This material provides the materials of worksheet focusing about education and daily activities. Types of input shows that $52 \%$ of the students chose the presentation of long $20 \%$ equal interesting $80 \%$. So, based on the input types that the students want, the text of material provides set and interest to help students learning writing. Learning procedure in the learning activity, $60 \%$ of the students wanted to have the activity of practicing the technique that can help to process the idea to be the product of writing. Learning grammar procedure in order to improve their knowledge of grammar, $44 \%$ of the students wanted to complete paragraph with grammatical correct sentences.

Writing activities for students shows that $36 \%$ the students wanted to do activities both in small group individual. This worksheet provides the activities which are done for small group and individual. Learners' role shows that in the process of learning, $44 \%$ of the students wanted to listen to the teacher's explanation and take a not, while $40 \%$ of the students to listen to the teacher's 
instruction. Teachers' role shows that most of the students $(68 \%)$ wanted that in the process of learning, the teacher acts as the resource who gives the source of information and give the example before he/she asks you to practice writing. The students also wanted the teacher acts as organizer and prompter (16\%).

Text-less comic for language criteria shows that most of the students agree with the understandable worksheet (64\%). Font criteria shows that most of the students agree with the selection of fonts, sizes and spaces used make it easier for them to read the material. Instruction criteria shows that most of the students agree with the instruction for activities in the students' material are clear, making it easier for them to do all activities. Content criteria shows that most of students agree with for each chapter there is exercise for they to practice.

The result of expert judgements presented in the following table:

The Result of Expert Judgment of Materials

\begin{tabular}{|c|c|c|c|c|}
\hline \multirow[t]{2}{*}{ No. } & \multirow[t]{2}{*}{ Statements } & \multicolumn{2}{|l|}{ Scores } & \multirow[t]{2}{*}{ Mean } \\
\hline & & Expert 1 & Expert 2 & \\
\hline 1. & $\begin{array}{l}\text { Materi yang disajikan dalam } \\
\text { website ini sesuai dengan standar } \\
\text { kompetensi dan kompetensi dasar } \\
(2013) \text {. }\end{array}$ & 5 & 5 & 5 \\
\hline 2. & $\begin{array}{l}\text { Materi yang disajikan dalam } \\
\text { website ini menggunakan tata } \\
\text { bahasa yang baik dan benar. }\end{array}$ & 4 & 4 & 4 \\
\hline 3. & $\begin{array}{l}\text { Materi dalam website ini disajikan } \\
\text { dan disusun dengan menarik } \\
\text { sehingga dapat menambah motivasi } \\
\text { siswa untuk belajar. }\end{array}$ & 4 & 5 & 4.5 \\
\hline \multicolumn{2}{|c|}{ Total Score } & 13 & 14 & 13.5 \\
\hline \multicolumn{2}{|c|}{ Average Score } & 4.3 & 4.6 & 4.5 \\
\hline
\end{tabular}

Table above is the summary from the expert judgment questionnaire which covers three general items of contents appropriateness: the content, language, and materials presentation. It is shown that the mean value of the appropriateness of all aspects is 4.5. It is categorized as "Strongly Agree" as its positions is in the 
interval $4.20<\mathrm{x}<5.00$. The appropriateness had been approved by the materials experts as shown in table above.

Finally, the conclusion from the results above is that the materials in the website has reached the standards of appropriateness. The conclusion is based on the expert's opinion which indicates the agreement on the appropriateness of this unit based on the standards proposed by $B N S P$ about learning materials for junior high school.

The Result of the Expert Judgment

The expert judgment questionnaire covered four aspects, such as:

The Appropriateness of the Language

\begin{tabular}{|c|c|c|c|c|}
\hline \multirow{2}{*}{$\begin{array}{l}\text { Item } \\
\text { Number }\end{array}$} & \multirow[b]{2}{*}{ Statements } & \multicolumn{2}{|l|}{ Score } & \multirow{2}{*}{ Mean } \\
\hline & & $\begin{array}{l}\text { Expert } \\
1\end{array}$ & $\begin{array}{l}\text { Expert } \\
2\end{array}$ & \\
\hline 1. & $\begin{array}{l}\text { Standardize the use of grammar in } \\
\text { general }\end{array}$ & 4 & 5 & 4.5 \\
\hline 2. & $\begin{array}{l}\text { Standardize the length of the } \\
\text { existing sentences in general }\end{array}$ & 4 & 5 & 4.5 \\
\hline 3. & $\begin{array}{l}\text { The appropriateness in using of } \\
\text { vocabulary in general }\end{array}$ & 4 & 5 & 4.5 \\
\hline 4. & $\begin{array}{l}\text { The appropriateness in using of } \\
\text { vocabulary }\end{array}$ & 4 & 5 & 4.5 \\
\hline 5. & $\begin{array}{l}\text { The appropriateness in using of } \\
\text { punctuation }\end{array}$ & 4 & 5 & 4.5 \\
\hline 6. & $\begin{array}{l}\text { The appropriateness in using of } \\
\text { capital letters in paragraphs }\end{array}$ & 4 & 5 & 4.5 \\
\hline 7. & The clarity or purity of meaning & 4 & 5 & 4.5 \\
\hline \multicolumn{2}{|c|}{ Total Score } & 28 & 35 & 31.5 \\
\hline \multicolumn{2}{|c|}{ Average Score } & 4 & 5 & 4.5 \\
\hline
\end{tabular}

It is shown by the table that the mean value of the appropriateness

of the language is 4.5 . It is categorized as "Very Good" as its position in the interval $4.20 \leq x \leq 5$.

1. The appropriateness of the content 
The Appropriateness of the content

\begin{tabular}{|c|c|c|c|c|}
\hline \multirow{2}{*}{$\begin{array}{l}\text { Item } \\
\text { Number }\end{array}$} & \multirow[b]{2}{*}{ Statements } & \multicolumn{2}{|l|}{ Score } & \multirow[b]{2}{*}{ Mean } \\
\hline & & $\begin{array}{l}\text { Expert } \\
1\end{array}$ & $\begin{array}{l}\text { Expert } \\
2\end{array}$ & \\
\hline 8 & $\begin{array}{l}\text { The developed material motivates } \\
\text { students in learning and writing }\end{array}$ & 4 & 5 & 4.5 \\
\hline 9 & $\begin{array}{l}\text { The developed material uses clear } \\
\text { language. }\end{array}$ & 5 & 5 & 5 \\
\hline 10 & $\begin{array}{l}\text { The developed material gives the } \\
\text { opportunity to students in using the } \\
\text { several of language in English. }\end{array}$ & 4 & 4 & 4 \\
\hline 11 & $\begin{array}{l}\text { The developed material motivates } \\
\text { students to make discussion. }\end{array}$ & 5 & 5 & 5 \\
\hline 12 & $\begin{array}{l}\text { The developed material uses the } \\
\text { exact and appropriate vocabulary. }\end{array}$ & 4 & 4 & 4 \\
\hline 13 & $\begin{array}{l}\text { The developed material can create } \\
\text { the circle of learning relax and fun. }\end{array}$ & 4 & 5 & 4.5 \\
\hline 14 & $\begin{array}{l}\text { The developed material enable to } \\
\text { students to apply learning strategy } \\
\text { effective and efficient. }\end{array}$ & 4 & 5 & 4.5 \\
\hline \multicolumn{2}{|c|}{ Total Score } & 30 & 33 & 31.5 \\
\hline \multicolumn{2}{|c|}{ Average Score } & 4.3 & 4.7 & 4.5 \\
\hline
\end{tabular}

It is shown by the table that the mean value of the appropriateness of the content is 4.5 It is categorized as "Very Good" as its positions in the interval $4.20 \leq x \leq 5$.

2. The appropriateness of the layout

The Appropriateness of the Layout

\begin{tabular}{|c|c|c|c|c|}
\hline \multirow{2}{*}{$\begin{array}{l}\text { Item } \\
\text { Number }\end{array}$} & \multirow[b]{2}{*}{ Statements } & \multicolumn{2}{|l|}{ Score } & \multirow[b]{2}{*}{ Mean } \\
\hline & & $\begin{array}{l}\text { Expert } \\
1\end{array}$ & $\begin{array}{l}\text { Expert } \\
2\end{array}$ & \\
\hline 15 & $\begin{array}{l}\text { The developed material is designed } \\
\text { appropriate with the students needed. }\end{array}$ & 4 & 4 & 4 \\
\hline
\end{tabular}




\begin{tabular}{|l|l|l|l|l|}
\hline 16 & $\begin{array}{l}\text { The material } \\
\text { accommodates in competence topics. }\end{array}$ & 4 & 4 & 4 \\
\hline 17 & $\begin{array}{l}\text { The kinds of vocabularies refer to } \\
\text { knowledge application in English. }\end{array}$ & 4 & 5 & 4.5 \\
\hline 18 & $\begin{array}{l}\text { The vocabularies unfamiliar is } \\
\text { translated }\end{array}$ & $\begin{array}{l}\text { The developed materials manage } \\
\text { students to rises the competence } \\
\text { effective and efficient. }\end{array}$ & 5 & 4 \\
\hline 20 & $\begin{array}{l}\text { The evaluation and estimation is } \\
\text { planned with the appropriate } \\
\text { competence. }\end{array}$ & 4 & 4 & 4 \\
\hline 21 & $\begin{array}{l}\text { The developed material division } \\
\text { develops in relevant. }\end{array}$ & 5 & 4 & 4.5 \\
\hline 22 & $\begin{array}{l}\text { The writing of developed material is } \\
\text { appropriate with the generic structure } \\
\text { of text. }\end{array}$ & 5 & 4 & 4.5 \\
\hline Total Score & 34 & 34 & 34 \\
\hline Average Score & 4.9 & 4.9 & 4,9 \\
\hline
\end{tabular}

3. The appropriateness of the layout

It is shown by the table that the mean value of the appropriateness of the layout is categorized as "Very Good" as its positions in the interval $4.20 \leq$ $x \leq 5$.

The Appropriateness of the Graphic

\begin{tabular}{|c|c|c|c|c|}
\hline \multirow{2}{*}{$\begin{array}{l}\text { Item } \\
\text { Number }\end{array}$} & \multirow[b]{2}{*}{ Statements } & \multicolumn{2}{|l|}{ Score } & \multirow[b]{2}{*}{ Mean } \\
\hline & & $\begin{array}{l}\text { Expert } \\
1\end{array}$ & $\begin{array}{l}\text { Expert } \\
2\end{array}$ & \\
\hline 23 & $\begin{array}{l}\text { The developed material size is } \\
\text { suitable with ISO standard. }\end{array}$ & 4 & 5 & 4.5 \\
\hline 24 & The worksheet design is interesting. & 5 & 5 & 5 \\
\hline 25 & $\begin{array}{l}\text { The font type and color can be read } \\
\text { easily. }\end{array}$ & 5 & 5 & 5 \\
\hline 26 & $\begin{array}{l}\text { The pictures and illustration are } \\
\text { relevant and reflected to the content }\end{array}$ & 5 & 5 & 5 \\
\hline
\end{tabular}




\begin{tabular}{|l|l|l|l|l|}
\hline & of the book. & & \\
\hline 27 & $\begin{array}{l}\text { The pictures and illustrations are } \\
\text { provided for aesthetic and functional } \\
\text { purposes. }\end{array}$ & 5 & 5 & 5 \\
\hline 28 & The title of each unit is consistent. & 4 & 4 & 4 \\
\hline 29 & The spaces between lines are normal. & 5 & 5 & 5 \\
\hline Total Score & 33 & 34 & 33,5 \\
\hline Average Score & 4.7 & 4.9 & 4.9 \\
\hline
\end{tabular}

appropriateness of the table It was categorized as "Very Good" as its positions in the interval $4.20 \leq x \leq 5$.

Finally, the mean value from all aspects it could be concluded that the material was categorized as "Very Good" since the position of the mean value was in the interval $4.20 \leq x \leq 5.1$.

\section{CONCLUSIONS AND SUGGESTIONS}

\section{CONCLUSION}

After analyzing the data, the conclusion was drawn as following:

The researcher developed the material by adjusting the material with the students' need. The need analysis was done by distributing a questionnaire in the form of multiple choices of 26 questions. There were 25 students who filled in the questionnaire. After conducting the need analysis, Developing students' writing material follows R \& D phases of Borg and Gall (2003) which is simplified into: 1) Gathering data and information, 2) Need analysis, 3) Designing the material, 4) Validating to expert, 5) Revising, and 6) Final Product. There were 25 students as the respondents in the class $\mathrm{X}$. Then the material was validated by the experts. In conclusion, based on the experts' evaluation, the developed descriptive writing material through text-less comic was appropriate to be used by the tenth grade students of SMA Gema Buwana. 


\section{SUGGESTIONS}

Best on the result, the writer also proposed validated material. In line with conclusions above, some suggestions are recommended as follows:

For the teachers

English teacher is one of the important points to make the teaching and learning process become successful. To achieve the goal study, the teachers should understand well the students' need in learning English more creative to force the students to write using the provided students' material. The teacher is suggested to add more sources to enhance the students' writing skill. If it is possible, the teacher can develop the appropriate material by conducting observation and need analysis because if the material can support students' need, they can make further development of the material.

For the students

The tenth grade students of Senior High School should create a communicative circumstance in the English classroom by being involved actively in English activities. The design material will not work well if the students do not participate actively in the teaching and learning process. They also need to do the tasks earnestly to improve their own writing skill.

\section{For the other researchers}

To the other researchers, they can develop the other students' material in the other English skill, such as: reading, listening, and speaking. It is also suggested for other developers to emphasize the needs of the learners and the demands of the curriculum. The developers also have to be more creative in the form of material to get the interest of students. 


\section{REFERENCES}

Alyani, Rochana Fitri. 2016. Developing Writing Materials by Using GenreBased Approach for the First Semester of the Tenth Grade Students at SMA Piri 1 Yogyakarta. Yogyakarta: Thesis. Universitas Negeri Yogyakarta.

Arikunto, S. 2013. Prosedur Penelitian. Jakarta: Rineka Cipta

Brown H.D. 1994. Principles of Language Learning and Teaching. Third Edition.

United States of America: San Francisco University.

Callaghan M and J Rothery. 1988. Teaching Factual Writing: Genre-based Approach. Sydney. DSP Marketing.

Dirgeyesa, I. 2016. Genre Based Approach: What and How to Teach and to Learn Writing. Medan: Unimed Press

Feez, S. And Joyce, H. 2002. Text-Based Syllabus Design. Sydney: NCECTR, Macquarie University.

Gee, S. 1997. Teaching writing: A genre-based approach. In : Fulcher, G. (Ed.). writing in the English language classroom. Hemel Hempstead: Pentrice Hall Europe ELT.

Harmer, J. 2007. The Practice of English Language Teaching. Edinburgh: Pearson Education Limited.

Hutchinson, T., and A. Waters. 1987. English for Specific Purpose. London:

Cambridge University press.

Hyland, K. 2004. Genre and Second Language Writing: Ann Arbor: University of Michigan Press.

Masitah, Siti \& Supriadji, Dasep. 2015. Improving Students' Ability in Writing Descriptive Text Using Genre Based Approach (GBA) at the Eight Grade

Students of SMP Islam Terpadu Fitrah Insani. ELTIN Journal Vol.3 (1).

Muhajirin, Muhammad. 2018. The Use of Comic Strips to Increase Students Writing Ability in Narrative Text Outline at The Eight Grade Students Of Mts Al-Arif Gempol. Sidoarjo: Thesis. Universitas Muhammadiyah Sidoarjo. 
Pardiyono. 2007. Pasti Bisa! Teaching Genre-Based Writing. Yogyakarta: Andi Publisher.

Pratiwi. Widyastuti Putri. 2017. Improving Students' Writing Skil Through Textless Comic. Surakarta. Thesis. Institut Agama Islam Negeri Surakarta.

Raimes, Ann. 1983. Techniques in Teaching Writing. Oxford: Oxford University Press.

Suseno, Anwar Aji. 2014. Developing Reading Materials Using a Genre-Based Approach for the Ninth Grade Students of SMP N 1 Depok in the First Semester. Yogyakarta: Thesis. Universitas Negeri Yogyakarta.

Triandari, Rizqie Oktanti. 2015. Developing Reading and Writing Learning Materials for Grade Eight Students of SMP Negeri 4 Magelang. Yogyakarta: Thesis. Universitas Negeri Yogyakarta. 